\title{
Trainee involvement increases precut rates and delays access to the common bile duct without an increase in procedure-related adverse events: a brave new world of ERCP training?
}

\author{
THEODOR VOIOSU ${ }^{1,2}$, ANDREI VOIOSU ${ }^{1,2}$, ANDREEA BENGUŞ ${ }^{1}$, MIHAI RIMBAŞ $^{1,2}$, BOGDAN MATEESCU ${ }^{1,2}$ \\ ${ }^{1} \mathrm{UMF}$ "Carol Davila" School of Medicine, Bucharest, Romania \\ ${ }^{2}$ Gastroenterology Department, "Colentina” Clinical Hospital, Bucharest, Romania
}

\begin{abstract}
Background and aims. Selective cannulation of the desired duct is a key element in ERCP procedures and an important step in the training of fellows. However, there is limited data about technical success and patient safety for ERCPs conducted in a training setting. We aimed to evaluate the impact of trainee involvement on the cannulation technique and procedure related outcomes at ERCP.

Materials and methods. We conducted an observational study of all ERCP conducted in an endoscopy unit with an on-going training program. Patient related data and procedure-related data (method of cannulation, time to cannulation, degree of trainee involvement, technical success and procedure-related adverse events) were collected using a standard form. The method of cannulation, time to cannulation and procedure-related adverse events were compared between ERCPs with trainee involvement and those without.

Results. 641 consecutive ERCPs were evaluated and 474 native papilla cases performed by 4 trainers and 3 trainees were included in the final analysis. Trainees were involved in 171 procedures (36.1\%), achieving cannulation of the desired duct in $50.8 \%$ of the cases. Cannulation rates were similar in the trainee group compared to the control group $(91.7 \% v s .88 .7 \%)$ and there was no increase in the rate of adverse events. However, cannulation time was significantly longer in the trainee group with a significant increase in the rate of precut use $(32.1 \% v s .23 .4 \%, \mathrm{p}<0.001)$.

Conclusions. Trainee involvement resulted in longer cannulation times and increased use of precut sphincterotomy, but, was not associated with an increased risk of procedure related adverse events.
\end{abstract}

Key words: ERCP; complications; endoscopy; training; outcome assessment.

\section{INTRODUCTION}

Selective cannulation of the desired duct is the cornerstone of successful ERCP procedures. Current guidelines recommend the wire-guided method as the initial approach to CBD cannulation and fistulotomy as the preferred method of precutting if conventional cannulation fails [1]. However, there is a wide variation in the practice of ERCP with regard to many technical aspects of cannulation including initial approach and precutting methods. Furthermore, data regarding the impact of trainee involvement on procedural aspects and outcomes, including cannulation technique, is scarce and sometimes contradictory [2-4].

An important challenge in teaching basic ERCP cannulation technique is how to balance the fellows' need for sufficient hands-on training time while not compromising patient safety through prolonged attempts at cannulation [5].We aimed to assess the impact of trainee involvement on can- nulation technique and success rate in a real-life teaching environment.

\section{MATERIAL AND METHODS}

We conducted a prospective observational study of ERCPs in a single referral center for therapeutic endoscopy. The study design was drawn according to the ethical guidelines of the 1975 Declaration of Helsinki and it was approved by the Local Ethics Committee at "Colentina" Clinical Hospital (2/04.03.2015) prior to study inception. All patients undergoing ERCP signed a standard written informed consent prior to the procedure.

\section{INCLUSION CRITERIA}

All ERCPs with a native papilla where diagnostic or therapeutic procedures in the CBD were planned prior to the procedure included in the analysis. 


\section{EXCLUSION CRITERIA}

Cases where the papilla could not be visualized or reached were excluded from our analysis. All cases where pancreatic duct cannulation was planned for diagnostic or therapeutic purposes were also excluded from our study; owing to the increased complexity and high-risk of these procedures as well as the limited number of cases treated in our unit, we considered it a potential bias in analyzing the role of trainee involvement in these particular procedures.

Patient related data (age, gender, indication for ERCP, final diagnosis) and procedure-related data (method of cannulation, time to cannulation, degree of trainee involvement, technical success and procedure-related adverse events) were collected using a standard form. When reporting, cannulation method was considered that method which directly led to the cannulation of the desired duct (i.e., wireguided cannulation, contrast injection, papillotomy etc.).

\section{ENDOSCOPIC INTERVENTION}

Our unit is a training center for ERCP, with a volume of over 500 procedures per year. A maximum of 3 fellows every year receive training in ERCP after demonstrating competency in diagnostic and therapeutic procedures in the upper and lower gastrointestinal tract. Although ERCP procedures are performed daily, not all procedures involve a trainee, depending on the trainee schedule of rotations.

Standard ERCP practice in our unit allows all trainees 10 minutes of conventional attempts at cannulation using a triple-lumen sphincterotome (Ultratome and Dreamtome, Boston Scientific) preloaded with a 0.035 -inch guidewire (Jagwire, Boston Scientific). If cannulation is successful during this interval, the trainee is allowed to carry on with the diagnostic and therapeutic procedures as planned. Trainers can intervene at any given time to ensure safe completion of the procedure by taking over the scope from their trainees. If cannulation fails after 10 minutes of attempts by the trainee, the supervisor continues with a cannulation method at his discretion, including precut sphincterotomy which is carried out using the papillotomy technique. There were no formal constraints placed on changing the cannulation method (i.e., from guidewireguided to contrast guided or even precut), either by the trainee or the trainer, at any time during the procedure, if deemed in the interest of the patient.
Also, there were no formal stopping rules for the procedure if cannulation failed, since we aimed to depict real-life conditions as accurately as possible.

In our unit, the use of intrarectal nonsteroidal anti-inflammatory drugs (NSAIDs) administered immediately after the procedure to all patients without contraindications is preferred to prophylactic pancreatic stenting as a method of choice for postERCP pancreatitis (PEP) prophylaxis.

\section{OUTCOME MEASURES}

Deep cannulation of the bile duct was considered the main outcome measure for our study. The rate of procedure-related adverse events as defined by Cotton et al. [6] was a secondary outcome measure for our study.

\section{SAMPLE SIZE ESTIMATION}

Based on data from our training program [7], estimating a 1:2 ratio of procedures with and without trainee involvement respectively (according to availability of a trainee in the ERCP room) and a cannulation rate of $85 \%$, we calculated that 429 procedures were required to detect a $10 \%$ difference in successful cannulation rates with $80 \%$ power and an alpha of 0.05 .

\section{DATA ANALYSIS}

Data was recorded and analyzed using SPSS 16 (IBM Corporation). Results are reported as means and standard deviations for variables with a normal distribution, and median, minimum and maximum respectively for variables with a nonnormal distribution. Univariate analysis was conducted using the Chi-square test for nominal variables, nonparametric tests for variables with nonnormal distribution (Mann Whitney U, Kruskall Wallis) and student $\mathrm{t}$-test for variables with normal distribution.

Multivariate analysis by logistic regression was used to analyze risk factors for deep biliary cannulation as well as procedure-related complications. Patient-related covariates (age, gender, bilirubin level, diagnosis) and procedure-related covariates (time to cannulation, cannulation method, trainee involvement) were included in the multivariate model. All covariates were tested for interaction using univariate analysis prior to inclusion in the multivariate analysis. Analysis was 2-tailed, with a $\mathrm{p}<0.05$ considered significant. 


\section{RESULTS}

641 consecutive ERCPs conducted in the Gastroenterology Division at "Colentina" Clinical Hospital between December 2015 and November 2016 were reviewed and 474 native papilla cases performed by 4 independent operators (range: $20-$ 242 procedures performed during the study interval) with prior experience in ERCP, fulfilling the in- clusion criteria, were included in the final analysis. Three trainees with limited experience in ERCP $(<50$ cases attempted each prior to the study period) were involved in 171 of these procedures (36.1\%).

The most frequent indication for ERCP was CBD stones which accounted for 272 cases $(57.4 \%)$, followed by pancreatic tumors in 90 cases $(19 \%)$ and cholangiocarcinoma in 42 cases $(9.1 \%)$. Patient characteristics are further detailed in Table 1.

Table 1

Patient characteristics

\begin{tabular}{|c|c|c|c|}
\hline & Trainee involvement & No trainee involvement & p-value \\
\hline Mean age, years $( \pm$ SD) & $66( \pm 17.6)$ & $65( \pm 16.7)$ & 0.87 \\
\hline Female gender & $87(50.8 \%)$ & $163(53.8 \%)$ & 0.63 \\
\hline \multicolumn{3}{|c|}{ Indication for ERCP } & \multirow{6}{*}{$0.047 *$} \\
\hline CBD stones & $97(56.8 \%)$ & $175(57.5 \%)$ & \\
\hline Pancreatic tumor & $30(17.6 \%)$ & $60(19.9 \%)$ & \\
\hline Cholangiocarcinoma & $14(4.6 \%)$ & $28(9.3 \%)$ & \\
\hline Bile leak/ trauma & $5(2.9 \%)$ & $11(3.7 \%)$ & \\
\hline Other & $28(16.1 \%)$ & $29(9.6 \%)$ & \\
\hline \multicolumn{3}{|c|}{ Papillary anatomy } & \multirow{4}{*}{0.1} \\
\hline Normal & $147(84.5 \%)$ & $276(91.1 \%)$ & \\
\hline$P A D$ & $24(12.1 \%)$ & $26(8.5 \%)$ & \\
\hline Postsurgical anatomy & $3(3.4 \%)$ & $1(0.4 \%)$ & \\
\hline Bilirubin levels (mg/dL) & $6.8( \pm 8)$ & $7.5( \pm 8)$ & 0.74 \\
\hline
\end{tabular}

*statistically significant using the Chi Square test

\section{PROCEDURE OUTCOME}

Cannulation of the CBD was achieved in 425 procedures $(89.9 \%)$. Cannulation time was under 5 minutes in 187 of these cases (44\%), between 5-10 mins in 119 cases (28\%) and more than 10 mins in 119 cases $(28 \%)$.

Trainees were involved in 171 procedures: in 84 of the cases (49.2\%) the trainee failed to achieve deep biliary cannulation, in 4 cases $(2.3 \%)$ only selective cannulation was achieved by the trainee while in further $25(14.6 \%)$ procedures the trainee managed partial success but did not complete the procedure unaided. In 58 cases $(33.9 \%)$ the trainee managed to carry out the complete procedure without hands-on assistance from the supervising endoscopist. Overall, trainee cannulation of the CBD duct was achieved in $50.8 \%$ of the attempted cases.

Successful cannulation of the CBD was achieved in 156 cases $(91.7 \%)$ where trainees were involved compared to 269 cases $(88.7 \%)$ without trainee involvement $(\mathrm{p}=0.34$ Chi Square). However, cannulation times were significantly longer in these cases, with only $26.3 \%$ of the procedures having a cannulation time of 5 minutes or less compared to $46.8 \%$ of the procedures without trainee involvement $(\mathrm{p}<0.001$ Chi Square) (Table 2, Figure 1A and 1B). On multivariate analysis, after adjusting for traditional co-factors such as patient age, gender, diagnosis and bilirubin levels, trainee involvement was not shown to be a risk factor for failed cannulation of the CBD.

With regard to cannulation method, there was a statistically significant increase in precut use in procedures with trainee involvement compared to those without trainee involvement (32.1\% vs. $23.4 \%$, $\mathrm{p}=0.04$ Chi Square). Furthermore, significantly more precut procedures in the trainee group occurred after more than 10 minutes of cannulation attempts compared to the control group (48/55 versus 30/71, p $<0.001$ Chi Square).

\section{PROCEDURE RELATED ADVERSE EVENTS}

A procedure-related adverse event was noted in 63 procedures $(13.4 \%)$. PEP was the most frequent $\mathrm{AE}$ (39 cases - 8.3\%), followed by cholangitis (3.2\%) and bleeding (2.5\%). Most of the AE were mild in severity (44 cases $-71 \%$ ), with severe AE occurring in only 5 cases $(8.1 \%)$. Six patients died in the 30 day-interval following the procedure $(1.1 \%)$, however only 3 deaths were 
related to procedural complications (2 cases of severe pancreatitis and 1 perforation, all of them in elderly patients with severe comorbidities as reflected by an ASA score of 3 or above).

There was no significant increase in the rate of $\mathrm{AE}$ in procedures where trainees were involved compared to procedures without trainee involvement $(15.2 \%$ vs. $12.2 \%, \mathrm{p}=0.34)($ Table 3$)$.
On multivariate analysis using logistic regression, after adjusting for patient co-factors (age, gender, bilirubin levels, diagnosis) and procedure related co-factors (trainee involvement, use of precut, failed cannulation) only bilirubin levels were significantly correlated with AE (OR 1.04; CI 95\% 1.003-1.092 for every $\mathrm{mg} / \mathrm{dL}$ increase in bilirubin levels).

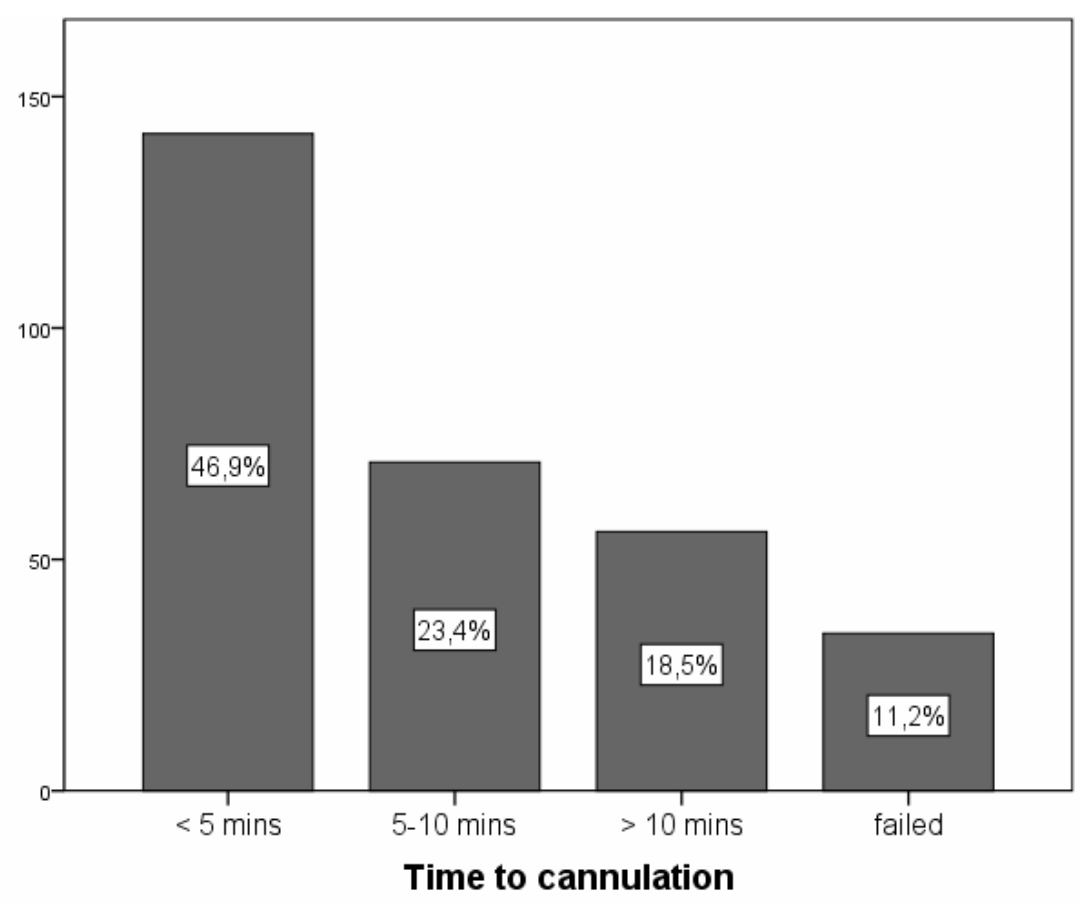

Figure 1A. Time to cannulation in the control group.

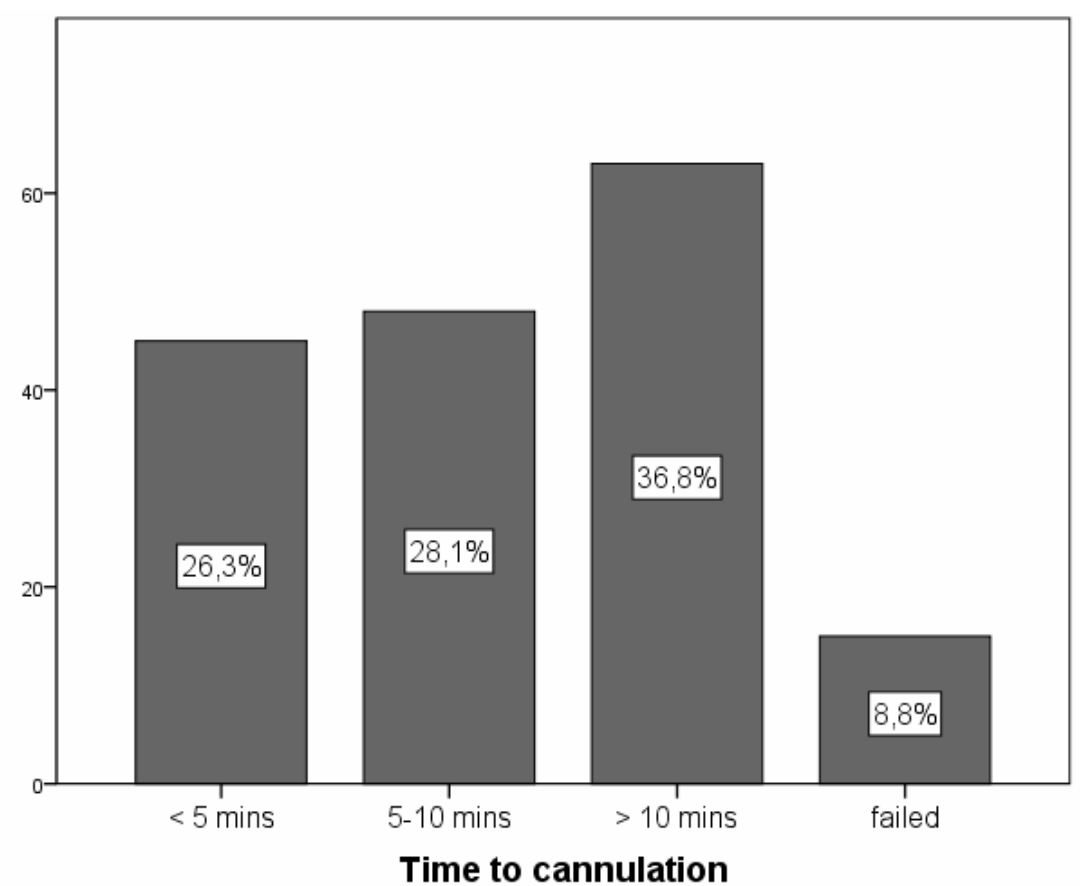

Figure 1B. Time to cannulation in the trainee involvement group. 
Table 2

Impact of trainee involvement on cannulation of the CBD

\begin{tabular}{|l|c|c|c|}
\hline & Trainee involvement & No trainee involvement & p-value \\
\hline CBD cannulation rates & $91.7 \%$ & $88.7 \%$ & 0.34 \\
\hline Time to cannulation & & & \multirow{2}{*}{$<0.001 *$} \\
\hline$<5$ mins & $45(25.8 \%)$ & $132(43.5 \%)$ & \\
\hline $5-10$ mins & $48(27.5 \%)$ & $71(23.4 \%)$ & \\
\hline$>10$ mins & $56(32.2 \%)$ & $56(18.4 \%)$ & \multirow{2}{*}{$\mathbf{0 . 0 4 9 *}$} \\
\hline Cannulation method & & & \\
\hline GW & $89(52 \%)$ & $189(62.4 \%)$ & \\
\hline Contrast-guided & $11(6.5 \%)$ & $8(2.7 \%)$ & \\
\hline DGW & $55(32.1 \%)$ & $71(23.4 \%)$ & \\
\hline Failed & $1(0.6 \%)$ & $2(0.6 \%)$ & \\
\hline
\end{tabular}

*statistically significant using the Chi Square test

Table 3

Comparison of adverse event rates between the two study groups

\begin{tabular}{|l|c|c|c|}
\hline & Trainee involvement & No trainee involvement & p-value \\
\hline Any AE & $26(15.2 \%)$ & $37(12.2 \%)$ & 0.34 \\
\hline PEP & $14(8.1 \%)$ & $25(8.2 \%)$ & 1 \\
\hline Cholangitis & $8(4.6 \%)$ & $7(2.3 \%)$ & 0.17 \\
\hline Bleeding & $6(1.9 \%)$ & $6(3.5 \%)$ & 0.3 \\
\hline Perforation & $1(0.3 \%)$ & $1(0.6 \%)$ & 1 \\
\hline
\end{tabular}

\section{DISCUSSION}

To our knowledge this is the first study analyzing the impact of trainee involvement on cannulation technique in a real-life setting.

The main finding of our study is the fact that trainee involvement significantly delays time to cannulation and also increases the rate of precut use compared to cases where trainees are not involved (from $23.4 \%$ to $32.1 \%$ ), without affecting CBD cannulation rates or increasing the rate of procedure-related adverse events.

These findings are particularly relevant in light of conflicting data regarding the timing of precut in cases where deep cannulation of the CBD is not swiftly achieved. Current data shows that prolonged attempts at $\mathrm{CBD}$ cannulation increase the risk of post-ERCP pancreatitis [8, 9]. Although precut sphincterotomy used to be regarded as an independent risk factor for PEP, emerging data suggests that prolonged attempts at cannulation rather than the use of precut in itself constitutes the main risk factor for PEP $[10,11]$. These observations have resulted in a paradigm shift, with current guidelines proposing a very stringent definition of what constitutes a difficult cannulation of the CBD (i.e., $>5$ minutes or 5 attempts and $>2$ pancreatic guidewire passages) [10]. As a direct result of this, some authors now advocate the use of precut as early as 5 minutes after the first attempt at con- ventional cannulation to minimize the risk of PEP [12].

The main issue with these recommendations is that their supporting data is derived mainly from studies carried out in referral centers by expert endoscopists, who are recognized to have superior results compared to low-volume endoscopists [13]. However, it is difficult to apply these observations in a real life setting, considering how a study of ERCP practice in the US [14] has proven that an overwhelming $75 \%$ of participating hospitals had an annual case load of $<100$ ERCPs. Furthermore, training in ERCP is far from being standardized with regard to case volume per fellow and the possibility of achieving competency during training [15-17]. A survey of ERCP fellows in the US showed that, although 2 out of 3 trainees did not reach competence in cannulation and sphincterotomy in accordance with existing quality standards and $30 \%$ of endoscopists reported inadequate ERCP training during their fellowship, over $90 \%$ of respondents planned to perform ERCP independently [18].

In light of these findings, it is currently unclear how the definitions of difficult biliary cannulation and the recommendations for early precut should be interpreted in the context of ERCP training, since they conflict with emerging data supporting the need to allow trainees a longer time to attempt cannulation in order to achieve adequate results [19]. 
The main advantage of our study is its observational design, allowing it to accurately show case and evaluate a real-life teaching environment. We aimed to analyze the way trainers reconcile the need for swift bile duct cannulation to minimize procedure-related adverse events with the trainees' need for prolonged attempts at cannulation in order to gain proficiency in this method. Our own training methods are based on previous observations showing that around 10 minutes of attempts are required to allow adequate cannulation rates for trainees, without compromising patient safety $[4,19]$.

While both groups achieved adequate cannulation rates of around $90 \%$, trainee involvement was associated with longer cannulation times and a significant increase in the rate of precut use. The timing of precut was also different, with most cases in the trainee group being delayed precut cases (> 10 minutes of failed attempts), while precut cases in the control group were mostly early precut cases $(<10$ minutes of failed attempts). Despite these differences, there was no increase in the rate of adverse events, including the rate of PEP in the trainee group, which is in accordance with previously reported data $[3,19]$.

Of note, the precut rate in our study was quite high, reaching $32 \%$ in the trainee group. This is considerably higher than the $11 \%$ precut rate we reported in an earlier study from our unit [7], reflecting perhaps a change in our own practice related to emerging data in support of early precut sphincterotomy over prolonged cannulation attempts. It is also worth noting that, despite the change of cannulation technique, the technical success and adverse events rate in our center have remained stable over time, and within the recommended quality standards parameters. Current guidelines recognize a wide variation in the use of precut, ranging from $5 \%$ to $31.5 \%$ of cases, with contradictory results with regard to the relationship between operator experience and procedure success as well as adverse events rate [1, 20-22]. However, most of the evidence cited comes from expert endoscopists working in large referral centers rather than from real-life observational studies.

The main limitation of our study is the fact that it is a single-center experience, including a limited number of trainers and trainees. Owing to important variations in the practice of ERCP from institution to institution, further multicenter trials are required to validate our data.

In conclusion, we believe this data supports the idea that trainers can and should adapt their cannulation strategies, including the use and timing of precut techniques, to allow trainees adequate training time without compromising procedurerelated outcomes and patients safety.

Declaration of Interest. The authors declare that there is no conflict of interest.

Introducere. Canularea selectivă a ductelor biliare sau pancreatice reprezintă un element cheie în desfäşurarea colangiopancreatografiei retrograde endoscopice (ERCP) şi un aspect foarte important în pregătirea endoscopiştilor. $\mathrm{Cu}$ toate acestea, dispunem de date limitate referitoare la succesul tehnic al procedurii şi rata de efecte adverse după ERCP-uri efectuate în cadrul programelor de pregătire în endoscopie. Am decis să evaluăm impactul participării unor endoscopişti incepători asupra tehnicii de canulare şi a rezultatelor procedurii endoscopice.

Materiale şi metode. Am desfăşurat un studiu observațional al tuturor procedurilor endoscopice desfăşurate întru-un centru de pregătire în ERCP. Datele referitoare la pacient şi aspectele procedurale (metoda de canulare, timpul până la canulare, gradul de implicare al endoscopistului în pregătire, succesul tehnic şi efectele adverse legate de procedură) au fost colectate folosind un formular standard. Am comparat metoda de canulare, timpul de canulare şi rata de efecte adverse postprocedurale intre lotul de proceduri efectuate de endoscopişti experimentați şi lotul de proceduri la care au participat şi începători.

Rezultate. 641 de proceduri consecutive au fost analizate, dintre care au fost incluse în studiu cele 474 de cazuri cu papilă nativă efectuate de 4 endoscopişti experimentați şi 3 incepători. 171 de proceduri au fost efectuate cu participarea incepătorilor (36.1\%), aceştia reuşind să canuleze singuri ductul dorit în 50.8\% din cazuri. Ratele de canulare au fost similare intre cele 2 grupuri (91.7\% vs. 
88.7\%) şi nu s-a constatat o creştere a ratei de efecte adverse în grupul incepătorilor. Timpul până la canulare a fost semnificativ mai lung în grupul incepătorilor, cu o utilizare mai frecventă a tehnicii precut pentru obținerea canulării selective (32.1\% vs. $23.4 \%, p<0.001)$.

Concluzii. Implicarea endoscopiştilor începători creşte timpul de canulare şi rata de utilizare a tehnicii precut, dar nu se asociază cu un risc crescut de complicații postprocedurale.

Correspondence to: Theodor Voiosu, MD, PhD, Gastroenterology Department,

"Colentina" Clinical Hospital, 19-21 Stefan cel Mare Bvd, Bucharest, Romania

Phone +40726732764

E-mail: theodor.voiosu@gmail.com

\section{REFERENCES}

1. TESTONI PA, MARIANI A, AABAKKEN L, et al. Papillary cannulation and sphincterotomy techniques at ERCP: European Society of Gastrointestinal Endoscopy (ESGE) Clinical Guideline. Endoscopy. 2016; 48(7):657-83.

2. WILLIAMS EJ, OGOLLAH R, THOMAS P, et al. What predicts failed cannulation and therapy at ERCP? Results of a largescale multicenter analysis. Endoscopy 2012; 44:674-83.

3. EKKELENKAMP VE, DE MAN RA, TER BORG F, et al. Prospective evaluation of ERCP performance: results of a nationwide quality registry. Endoscopy. 2015; 47(6):503-7.

4. KWEK BE, ANG TL, TEO EK, et al. Making ERCP training safe: a protocol based strategy to minimize complications during selective biliary cannulation. J Interv Gastroenterol 2012; 2:66-9.

5. HELLER SJ, TOKAR JL. Current status of advanced gastrointestinal endoscopy training fellowships in the United States. Adv Med Educ Pract 2011; 11:25-34.

6. COTTON PB, LEHMAN G, VENNES J, et al. Endoscopic sphincterotomy complications and their management: an attempt at consensus. Gastrointest Endosc 1997;37:383-93.

7. VOIOSU T, BENGUS A, VOIOSU A, et al. Trainee caseload correlates with ERCP success rates but not with procedurerelated complications: results from a prospective study (the QUASIE cohort). Endosc Int Open. 2016; 4(4):E409-14.

8. VANDERVOORT J, SOETIKNO RM, THAM TCK, et al. Risk factors for complications after performance of ERCP. Gastrointest Endosc 2002; 56:652-6.

9. DUMONCEAU J-M, RIGAUX J, KAHALEH M,et al. Prophylaxis of post-ERCP pancreatitis: a practice survey. Gastrointest Endosc 2010; 71:934-39.

10. DUMONCEAU JM, ANDRIULLI A, ELMUNZER BJ. Prophylaxis of post-ERCP pancreatitis: European Society of Gastrointestinal Endoscopy (ESGE) Guideline - updated June 2014. Endoscopy. 2014; 46(9):799-815.

11. SWAN MP, ALEXANDER S, MOSS A, et al. Needle knife sphincterotomy does not increase the risk of pancreatitis in patients with difficult biliary cannulation. Clin Gastroenterol Hepatol 2013; 11:430-6.

12. MARIANI A, DI LEO M, GIARDULLO N, et al. Early precut sphincterotomy for difficult biliary access to reduce post-ERCP pancreatitis: a randomized trial. Endoscopy. 2016; 48(6):530-5.

13. KAPRAL C, DULLER C, WEWALKA F, et al. Case volume and outcome of endoscopic retrograde cholangiopancreatography: results of a nationwide Austrian benchmarking project. Endoscopy. 2008; 40(8):625-30.

14. VARADARAJULU S, KILGORE ML, WILCOX CM, ELOUBEIDI MA. Relationship among hospital ERCP volume, length of stay, and technical outcomes. Gastrointest Endosc. 2006; 64(3):338-47.

15. ASGE TRAINING COMMITTEE., JORGENSEN J, KUBILIUN N, et al. Endoscopic retrograde cholangiopancreatography (ERCP): core curriculum. Gastrointest Endosc. 2016; 83(2):279-89.

16. ANG TL, CHENG J, KHOR JL, et al.Guideline on training and credentialing in endoscopic retrograde cholangiopancreatography Singapore Med J. 2011; 52(9):654-7.

17. VERMA D, GOSTOUT CJ, PETERSEN BT,et al.Establishing a true assessment of endoscopic competence in ERCP during training and beyond: a single-operator learning curve for deep biliary cannulation in patients with native papillary anatomy. Gastrointest Endosc. 2007; 65(3):394-400.

18. KOWALSKI T, KANCHANA T, PUNGPAPONG S. Perceptions of gastroenterology fellows regarding ERCP competency and training. Gastrointest Endosc. 2003; 58(3):345-9.

19. PAN Y, ZHAO L, LEUNG J, et al. Appropriate time for selective biliary cannulation by trainees during ERCP - a randomized trial. Endoscopy. 2015; 47(8):688-95.

20. FIGUEIREDO FA, PELOSI AD, MACHADO L,et al. Precut papillotomy: a risky technique not only for experts but also for average endoscopists skilled in ERCP. Dig Dis Sci 2010; 55:1485-9.

21. HAREWOOD GC, BARON TH. An assessment of the learning curve for precut biliary sphincterotomy. Am J Gastroenterol 2002;97:1708-12.

22. AKARAVIPUTH T, LOHSIRIWAT V, SWANGSRI J, et al. The learning curve for safety and success of precut sphincterotomy for therapeutic ERCP: a single endoscopist's experience. Endoscopy 2008; 40:513.6.

Received October $9^{\text {th }}, 2017$ 